This is the version of the article/chapter accepted for publication in International Journal of Drug Policy, 89 (103115) published by Elsevier https://doi.org/10.1016/j.drugpo.2021.103115

Accepted version downloaded from SOAS Research Online: http://eprints.soas.ac.uk/35172

(C)2021. This manuscript version is made available under the CC-BY-NC-ND 4.0 license http://creativecommons.org/licenses/bync-nd/4.0/

Title: Critical policy frontiers: The drugs-development-peacebuilding trilemma

Authors, affiliations and email addresses:

\title{
Jonathan Goodhand
}

Department of Development Studies, SOAS University of London 10 Thornhaugh Street, Russell Square, London, WC1H 0XG

Email address: jg27@soas.ac.uk

\section{Patrick Meehan}

Department of Development Studies, SOAS University of London 10 Thornhaugh Street, Russell Square, London, WC1H 0XG

Email address: pm42@ soas.ac.uk

\section{Jasmine Bhatia}

Department of Development Studies, SOAS University of London 10 Thornhaugh Street, Russell Square, London, WC1H 0XG

Email address: jb106@ soas.ac.uk

\section{Maziyar Ghiabi}

Department of Development Studies, SOAS University of London 10 Thornhaugh Street, Russell Square, London, WC1H 0XG

Email address: mg88@ soas.ac.uk

\section{Francisco Gutiérrez Sanín}

Instituto de Estudios Políticos y Relaciones Internacionales, Universidad Nacional de Colombia

Email address: fgutiers@ @otmail.com 


\title{
Title: Critical policy frontiers: the drugs-development-peacebuilding trilemma
}

\section{Keywords}

drug policy; borderlands; drugs and development; drugs and (dis)order, policy trade-offs

\begin{abstract}
Recent years have seen the emergence of a policy consensus around the need for fundamental reforms of global drug policies. This is reflected in the call for 'development-oriented drug policies' that align and integrate drug policies with development and peacebuilding objectives, as captured in the Sustainable Development Goals (SDGs). These calls have been important in acknowledging the damage caused by the war on drugs and in drawing attention to how drugs are inextricably linked to wider development and peacebuilding challenges. Yet there is surprisingly limited academic research that looks critically at the drugs-development-peace nexus and which asks whether the goals of a 'drug-free world', 'sustainable development' and 'the promotion of peace' are commensurate with one another, can be pursued simultaneously, or are indeed achievable. This articles studies these policy fields and policy-making processes from the geographical margins of the state - frontiers and borderland regions - because they offer a privileged vantage point for studying the contested nature of policymaking in relation to the drugs-development-peace nexus. We set out a historical political economy framework to critically assess the assumptions underlying the integrationist agenda, as well as the evidence base to support it. By developing the notion of a policy trilemma we are critical of the dominant policy narrative that 'all good things come together', showing instead the fundamental tensions and trade-offs between these policy fields. In exploring the interactions between these policy fields, we aim to advance discussion and debate on how to engage with the tensions and tradeoffs that this integrationist agenda reveals, but which have to date been largely ignored.
\end{abstract}

\section{Introduction}

Recent years have seen the emergence of a policy consensus around the need for fundamental reforms of global drug policies. This is reflected in the call to align and integrate drug policies with development and peacebuilding objectives, as captured in the Sustainable Development Goals (SDGs) (Buxton, 2015, 2; Brombacher \& Westerbarkei, 2019; Gillies et al., 2019; GIZ, 2013; UNODC 2016). Yet the evidence base to support this new alignment is limited and there has been a dearth of critical academic research that focuses on the drugs-developmentpeace nexus. To what extent are the goals of the international drug control regime, sustainable development and the promotion of peace commensurate with one another? What happens when these three policy fields converge, and become entangled with one another in drugs-affected 
borderland regions? What are the tensions and trade-offs involved in pursuing multiple objectives?

Drawing upon an historical political economy framework we scrutinize the assumptions underlying the integrationist agenda, as well as the evidence base to support it. We are critical of policy narratives claiming that 'all good things come together', and instead present a policy trilemma that outlines the fundamental tensions and trade-offs, as well as the complex entanglements, between these policy fields. In exploring the interactions between these policy fields, we aim to advance debate on how to engage with these tensions and trade-offs which have to date been largely ignored.

Central to our approach is a focus on the geographical margins of the state - frontiers and borderland regions. We argue that these spaces offer a privileged vantage point for studying the contested nature of policymaking in relation to the drug-development-peace nexus (Asad 2004; Das et al., 2004; Goodhand, 2020; Goodhand, 2008b; Raeymaekers, 2013). Borderlands are places of ambivalence and contradictions, generating both anxiety and neglect; they are perceived as disruptive spaces, sources of insecurity and illicit drugs, which prompt coercive and pacifying forms of intervention. At the same time, they frequently suffer from 'neglect', typically manifest in a lack of public services and social welfare provision. Yet 'unruly' borderlands are also sites of innovation and transformation; both in relation to the dynamics of illicit economies and as laboratories of policy experimentation. Rather than being passive receptors of external policies, we see borderlands as places with profound and far-reaching effects on centres of power and law making. Therefore studying the margins may tell us important things about the centre; or to put it another way, the character of the whole is illuminated by attention to the edge. 
The article proceeds as follows: First, we briefly define policymaking in relation to the fields of drugs, development and peacebuilding. Second, we look critically at positivist models of policymaking. Third we map out an alternative political economy approach, informed by an analysis of power, space and time. Fourth we use this framework to explore the inherent tensions and trade-offs between, and the distributional effects of, these three policy fields. Fifth we tentatively map out some of the policy implications of the foregoing analysis.

\section{Defining policymaking and the policy fields of drugs, development and peacebuilding}

Drug policy scholars have long dwelled on what is a policy and how policy ought to be studied. Much of this scholarship has focused on the process of policymaking in advanced industrialised economies, and from a quite narrow and formalistic viewpoint in which policy is understood as 'a set of interrelated decisions concerning the selection of goals and the means of achieving them within a specific situation' (Jenkins, cited in Bewley Taylor, 2014, 1011). However, a growing body of scholarship - much of it focused on harm reduction strategies - has adopted a more expansive conception of policy and policy-making (Ritter 2009; Stevens \& Ritter 2013; Fraser 2016; Lancaster et al., 2018; Fraser 2020). This literature treats policymaking and 'evidence making' as political processes that are deeply entangled in and generative of the phenomenon - drug use, public health, crime - they purportedly seek to address. Drawing on this literature we likewise adopt a broader conception of policy and policymaking. Building on the work of Carol Bacchi (2012) and others (Rhodes, 2002; Buxton, 2015; Lancaster et al., 2018), we do not assume a sharp distinction between 'design' and 'implementation' or 'practice'. Our conception of policymaking covers a wide range of activities, from the global (mission statements, strategic plans, policy fora and consultations) to the programmatic or project level (designs, models, strategies, implementation). This approach aligns with insights 
from the emerging drug policy literature, which highlights the performativity of policy processes (Campbell \& Campbell, 2000; Race, 2011; Lancaster, 2016) and the politics of knowledge production at national (Lancaster et al., 2017) and international levels (Singleton \& Rubin, 2014; Ghiabi, 2018).

The policy fields of drugs, development and peacebuilding are conceived here as being distinct but inter-dependent. Rather than being the preserve of formal actors and processes, we understand these policy fields as more open and amorphous involving an amalgam of informal actors and processes, negotiating policies that are frequently neither documented nor written down (Shore \& Wright, 2003). Policies are mediated through the activities of public institutions as well as through social repertoires, everyday practices and informal or clandestine networks. These policies travel across different spaces and scales, spanning drug markets and drug use in advanced industrialised countries, through to drug production, consumption and trade in the borderlands of some of the poorest countries. Policymaking rarely flows downwards and outwards in a smooth top down, centre-periphery fashion (Peck \& Theodore, 2012). The idea that Washington, Vienna, or London, or alternatively Bogota, Nay Pyi Taw, or Kabul are the wellsprings of policy, misses the decentred, complex and shifting nature of policy processes. In conflict- and drug-affected borderlands, drug policy converges with the peacebuilding and development fields, leading to complex entanglements and points of friction, that have wider ramifications for international policymaking. Much recent scholarship, however, has been neglectful of the dynamics of drug policy in the Global South, especially in drug producing countries, where drugs are a vital source of livelihoods and where issues of illicit trade, consumption and enforcement produce a mixture of harms and benefits. This remains a field of utmost importance to understand and shape global drug policy and development. 
The boundaries between the policy fields of drugs, development and peacebuilding are fuzzy and contested, and there are sub-systems within each - for example 'harm reduction' is a subfield with a distinct epistemic community, whilst at the same time cutting across the drugs and development policy fields. But competing mandates and funding streams, different organisational cultures, approaches and partnerships reinforce the boundaries between these policy fields. Drugs agencies, such as the UNODC, for example, tend to work through stateto-state partnerships and top-down modalities and programmes, whilst development organisations tend to stress more bottom-up, participatory methodologies involving civil society, the private sector, and local state institutions. Distinct funding streams and the dominance of national-level institutions in drug policymaking often create a disjuncture between drug control agencies and local civil society organisations active on drug issues.

On the ground, there is often a fundamental disconnect between the agencies working on/against drugs, and those working on development and peacebuilding. Development actors tend to treat drugs as a 'taboo' subject (Buxton, 2015). Conversely, drug policymakers frame drugs as primarily a criminality and security issue (United Nations Office on Drugs and Crime, 2010), which undermine the stability of the state and impede developmental goals (United Nations Office on Drugs and Crime, 2010; Buxton, 2015; Meehan, 2015). Whilst these labels and mandates carry significance for the agencies themselves, they make little sense for local communities and public officials attempting to grapple with the deeply interconnected challenges of violence, illicit economies, chronic poverty and community welfare.

As a result, organisational mandates and predispositions mean that drugs, development and peace/security are conceived as discrete problems, to be treated through separate policy measures. Gutierrez (2020) notes that the World Bank country diagnostics make no mention 
of illicit drugs, while UNODC drug reports typically fail to engage with wider structural drivers of drug production. Yet this separation of drugs and development makes little sense if one considers how illicit drug production is entangled with a complex set of interlocking development issues and deficits including indebtedness, insecurity, lack of property rights and minimal citizenship rights (Duclos, 2011).

However the interrelationships between these phenomena are increasingly acknowledged, and there is a demand for more 'joined up' approaches. A range of factors are driving this integrationist agenda, which has hitherto been driven by the work of Non-Governmental Organisations (NGOs), such as the International Drug Policy Consortium and Christian Aid (Melis \& Nougier, 2010; Gutierrez, 2015). Firstly, these policy fields are shaped by structural processes, linked to broader shifts in global governance in the aftermath of the Cold War. There has been a trend towards more ambitious, expansive and approaches, because of a loosening of western governments' inhibitions to intervene, and relatedly changing perceptions of risk; fragile states, illicit economies, maldevelopment and migration are framed as urgent security issues, directly threatening the interests and stability of western countries. This has contributed to the reframing of drugs, development and peacebuilding as investments in 'stabilisation', 'resilience', human security and so forth (Duffield, 2007; Keen \& Andersson, 2018; Woodward, 2017).

Secondly, there are institutional interests driving this convergence. The rebadging or relabelling of programmes, the forging of new connections and the generation of new justifications for intervention are often linked to crises of legitimacy and the need to gain access to new revenue streams. For instance Tate (2015) highlights how Plan Colombia was a godsend to the US and Colombian militaries in a post-Cold War environment where there were 
strong pressures to downsize or find new roles for the military. The trend for drugs actors to reframe their work in development terms can at least in part be understood as a play for resources, just as development actors have recast their programmes in recent years as a vital investment in peacebuilding or stabilisation. The integrationist agenda is cloaked in the language of 'win-win solutions', but like other development buzzwords such as 'participation' and 'good governance' this language hides underlying conflicts, power struggles, battles over resources and the allocation of meaning. They veil the fundamental trade-offs involved in pursuing different policy goals. For example, the World Drug Report (2010) claims that 'more development means less crime and less conflict' and that the reduction of drug supply and drug trafficking 'can help foster peace'. In a subsequent World Drug Report (2015), drugs are presented as part of a 'vicious circle' linked to bad governance and the escalation of conflict. As a counterpoint to this, a 'virtuous cycle' involving counter narcotics, development and peacebulding is advocated.

Thirdly, there is the empirical reality of these policy fields converging and colliding in borderland sites. This dynamic of convergence, particularly on the margins of the state, is rarely a hegemonic, uncontested and smooth process. More often, it generates frictions and collisions and attempts by policymakers to redraw and sharpen institutional and programmatic boundaries linked to competing mandates and funding streams. We return to these tensions and trade-offs later.

\section{The Temptations of the Technical: Dominant understandings of policymaking}

Notwithstanding the extensive critiques of instrumentalist, problem-solving approaches to policy, a positivist mindset still retains a strong foothold in the policy fields of drugs, development and peacebuilding. This is manifest in several ways: 
Firstly, there is a tendency towards ahistorical thinking or what has been called liberal amnesia (Cramer, 2006). History, if considered, is largely seen as a backdrop and drugs-affected borderlands are treated as blank slates on which to enact a package of transformative policy measures. Secondly, teleological thinking is manifest in the developmentalist 'conceit of progress' (Edwards, 1999; Mosse, 2004), the notion of a linear transition from 'war' to 'peace' and the idea of statebuilding - or 'getting to Denmark' (Fukuyama, 2014) - as a project of convergence around a liberal model of the state (World Bank, 2011; Ghani \& Lockhart, 2008; DFID, 2010). Thirdly there is a tendency towards reification, which is particularly manifest in drugs fetishism in the sense that drugs are abstracted from their social, cultural and political contexts and are imbued with particular qualities and powers. For instance, it is taken as axiomatic that: poppy farmers are purely motivated by price signals; drugs are intrinsically a 'conflict good' triggering violence and insurgency (e.g. Cornell, 2005; Sullivan, 2012); and shifts and reductions in drug production can be primarily attributed to drug policies rather than broader contextual factors (Drugs and (dis)order, 2020; Mansfield, 2016).

Fourthly, there is the tendency for policymakers to define problems in terms of their ability to respond to them. Problem identification involves the drawing of sharp boundaries around complex social and political realities in order to generate 'viable solutions', i.e. responses that aid organisations can deliver. Solutions are constructed in primarily technical terms, filtering out the essential messiness and the politics that surrounds them. This temptation of the technical (Carothers \& de Gramont, 2013) or the 'tyranny of experts' (Easterly, 2014) serves a number of functions: it provides policymakers with a sense of purpose and certainty in highly unpredictable and contested environments; it legitimizes interventions as being 'scientific' and 
evidence based (see below); it masks the underlying sets of interests, political, institutional, financial that frequently drive policies.

Fifthly, these policy reflexes frequently align with a statist orientation amongst policymakers, producing what we have termed 'borderland blindness' (Goodhand, 2020). This blindness is deeply embedded and reinforced in the mental maps and organizing principles of the policymaking industry - the division of the world into country teams, the national planning and budgeting processes, the location of country offices in capital cities. These all contribute to capital city biases and a silencing of borderland perspectives (Goodhand, 2020).

All five reflexes lead to an underplaying or filtering out of contextual factors and an exaggerated and distorted understanding of 'the problem' and the transformative powers of 'the solution'. These reflexes are reinforced by the ways in which evidence is collected, filtered and interpreted, particularly, but not exclusively, within the drug policy field. Policies are selected, shaped and justified because they are seen to be 'scientific' and evidence-based. They draw upon proven methodologies to gather data, which is used to develop models, theories of change and evidence about 'what works'. Targets and metrics of success are generated, based on this evidence and underlying theories of change - from number of poppy fields eradicated, to drug seizures, to attainment of SDG goals, to reduced levels of armed conflict.

In spite of the claim to scientific validity, 'success' tends to be defined by external experts, and is shaped by dominant political interests and power structures - as manifest in the overwhelming focus on the eradication of drug production in the Global South rather than the targeting of demand reduction in northern countries. The doctrine of drug eradication remains the axiom guiding policy in the international field.. This state of affairs suggests that it may 
often be a case of policy-based evidence rather than evidence-based policy; evidence is used selectively to support a priori positions, which are largely informed by strategic calculi, ideologies, beliefs and ethics.

A failure to achieve benchmarks of success, and growing recognition of policy failures, lead to institutional crises and a call for reform in order to re-legitimise and reinvent the policy field. In her study of international engagement in Afghanistan Astri Surkhe (2011) argued that the reaction to growing evidence of failure was a 'critical mass' approach; a call for greater investment and more expansive approaches, leading to more intrusive policy interventions in which the war on drugs, the war on terror, statebuilding and development were all seen as being mutually reinforcing, in spite of the evidence that they were generating perverse effects on Afghan society and undercutting one another. The call for more developmental approaches to drugs needs to be viewed in this light; there is a recognition that problems need to be defined more broadly, which has led many to call for more expansive and integrated approaches. But this, as we unpack further below, is based upon a problematic assumption that 'all good things come together' (Hirschman, 1967).

\section{An Alternative framework: Power, Space and Time}

As noted above, there is a long established critique of positivist and managerial approaches to policy (Autesserre, 2014; Mosse, 2004; Mosse, 2011; Bacchi, 2016; Cheng, Goodhand \& Meehan 2018; Ferguson, 1994; Li, 2007; Khan, 2010). This body of literature provides a more nuanced and complex understanding of policymaking processes. It emphasizes the inseparability of 'policy science' and politics in open systems characterized by complex causality, contingency and uncertainty, and draws attention to the mobile, multi-level, multisited nature of policymaking. 
Drawing upon these insights, we set out below a framework for analysing and better understanding policymaking processes and their impacts in drugs- and conflict-affected borderlands. This framework - which centres on questions of power, space and time challenges how policymakers currently conceptualise and respond to drugs, armed conflict and development. First, we argue that the framework helps re-conceptualise the borderland environments in which policymakers intervene and the impacts of their interventions. Second, the framework 'turns the mirror inwards' by highlighting the internal dynamics and contentious politics within and between the policy fields of drugs, development and peacebuilding.

\subsection{Power (political economy)}

At the core of our analytical framework is a political economy approach, which focuses on how policymaking processes and interventions are saturated with, and shaped by, questions of power and vested interests. Growing calls to integrate drugs, development and peacebuilding policies embody a comprehensive, ambitious and transformative agenda. They seek to radically 'rewire' and transform drugs-affected borderlands by tackling conflict dynamics, building state capacities in areas of limited or contested statehood, catalysing economic development, and addressing illicit economies that underpin local power configurations. In Afghanistan and Colombia, for example, external funding has been allocated towards security related assistance for the military and police alongside drugs eradication and interdiction. In Myanmar and Laos, China has sought to transform the local economy through large-scale agribusiness development and major infrastructure projects in an attempt to reorient the local economy away from opium production (Meehan, this volume; $\mathrm{Lu}, 2017$; $\mathrm{Su}, 2015$ ). 
Interventions in conflict- and drug-affected borderlands map onto highly complex and volatile spaces; where power and politics exist in a "nexus of formality and informality" (Ghiabi, 2020), sovereignty is highly fragmented, the means of violence are diffuse, and the state is just one of multiple sources of public authority. These are spaces where "the brutal politics of sovereignty" continue to play out, and where stability is often predicated on coalitions and bargaining arrangements between a wide array of actors (Goodhand, 2009, 9). In such contexts, illicit drug economies are deeply embedded in local configurations of power. The potential for high profits - linked to the risk premium attached to drug refining and trafficking - means that drugs provide opportunities to accumulate capital, establish patronage networks and finance coercion. Threats of prosecution, promises of impunity and access to the legal economy mean that drugs become central to coalition management and bargaining processes (Meehan, 2015). The global war on drugs, and in some contexts pressures from local communities to tackle drug supply and consumption (see Dan, Maran \& Sadan, this volume), becomes enmeshed in these bargaining processes which involve plays for resources and legitimacy.

Interveners typically portray themselves as external to the contexts they engage with, as neutral referees rather than active players (Cheng, Goodhand \& Meehan, 2018, 82; de Waal, 2009). Instead, greater attention must focus on how interventions shape, and become entangled with material interests (coercive power, financial resources, patronage structures) and non-material resources (legitimacy, norms, beliefs, values) as they enter into volatile and contested political spaces (Rhodes \& Lancaster, 2019). Policies related to drugs, development and peacebuilding, rather than being seen as an external antidote to internal problems, need to be reframed as inherent to the political economy of drugs- and conflict-affected borderlands. As Christine Bell $(2015,16)$ argues, a political economy analysis "does not just point to the need for development actors to understand local political actors better, it points to the fact that development actors 
will need to understand their own decisions as political and try to reconcile them with their normative commitments."

A political economy approach also emphasizes the need to focus on the 'distributive' impacts rather than just 'aggregate' impact of policy. Drug policies have typically gauged success through aggregate measures, such as reduction in land under cultivation, amount of crops eradicated or volumes of drugs interceded. For example, the peace process in Colombia been dominated by a 'zero-coca' approach, in some cases tying coca eradication to state assistance programs (Felbab-Brown, 2020). While in the eyes of policymakers these measures may represent net social benefits, their costs are distributed highly unevenly between different social groups and across different spaces and scales - something that is overlooked in narratives that promise ‘win-win' solutions.

There has been growing acknowledgement amongst policymakers of the need to take questions of politics and power seriously and to integrate them into planning (DFID, 2010; Gravingholt ,2011; Ingram, 2014/2015). However, this political economy lens is typically focused on the contexts where interventions take place, and does not 'turn the mirror inwards' to integrate questions of politics and power into the study of policymaking processes themselves (Cheng, Goodhand \& Meehan, 2018). There is a need for greater focus on the vested interests, points of friction, institutional pressures, conflicts, tensions, and trade-offs that exist within and between policy fields and interventions. Interveners are themselves part of a political economy and set of market forces - geopolitically, institutionally and financially. Such organisations have 'soft' interests (declared goals and principles) and underlying 'hard interests' (market share, profile, professional status) (De Waal, 1997). The official rules of the game and the rules in use may be quite different, reflecting significant gaps between stated goals and 
underlying interests. For example, Keen and Andersson (2018) argue that the security paradigms surroundings drugs, terrorism and migration can be better understood less by how effective they are in achieving stated goals, than by the distribution of costs of benefits that are accrued by the assemblage of actors involved. Although policies surrounding drugs, migration and terrorism may 'fail' on a global level according to their stated aims (for example, reducing levels of drug supply), they succeed in achieving a set of unstated goals: they reframe complex issues in narrow political terms, which concentrates attention on supply counties in the Global South, and determine who has the power to set policy agendas; they reward various actors involved in these policies; and they involve a process of risk transfer in which the most marginal actors, including drug producers and users in low-income countries, bear the brunt of the violence and stigmatisation associated with these policies. A political economy approach goes beyond a focus on whether interventions work - something that creates a narrow and technical fixation on measuring success against stated goals - in order to better understand how they work and who for. As David Mosse (2004) argues, the fixation on success or failure of interventions against stated goals obscures the complex work that policy performs in enrolling different audiences and stakeholders, with different sets of interests. Policy 'success' is as much about performance and representation - the ability to mobilise diverse groups - as it is about the achievement of stated goals. A political economy analysis of policymaking processes reveals the complex and contradictory sets of interests within and between intervening actors and how the subsequent bargaining processes and power-plays surrounding interventions can shape policy outcomes. The integrationist agenda promises a greater synergy between the policy fields of drugs, development and peacebuilding, which have hitherto been largely siloed. However, calls for greater alignment tend to skirt over the underlying economic and geopolitical interests, and hidden loyalties, tensions, ideologies and hubris that continue to shape these policies. 


\subsection{Space}

In addition to being more conscious of the politics of policy, there is a need for a more explicit recognition of its spatial dimensions. Greater sensitivity to issues of space and scale brings into focus, first, the need to challenge 'borderland blindness' so as to better understand the complexities and sensitivities of borderland spaces and the challenges they pose to policymakers, and second, the need to analyse the fluidity and multi-scalar nature of policymaking itself.

"The centrality of territory in state self-definition" has meant that control over international borders remains a priority for states, albeit a deeply problematic one in many parts of the world where "states are 'younger' than the societies they purport to administer and the demarcation of borders preceded nation-building" (Goodhand, 2008, 228; van Schendel 2013, 267). Trade, migration, capital flows and familial networks have historically extended beyond the national borders constructed by states (Sadan, 2013). This has created identities, loyalties, institutions and resource flows beyond the purview of the state and which challenge state elites' efforts to construct "exclusive national cultures" (Paasi, 2003, 111). As a result borderlands are often “sensitive spaces" for states (Cons, 2016; Goodhand, this volume; Koehler \& Moosekhel, this volume). They are frequently places with an insurrectionary tradition, where monopolies over the means of coercion are disputed, law and order is perceived to be limited, and loyalties are questionable.

Policymakers have often embraced a "diffusionist" narrative and associated set of measures as an antidote to the 'pathologies' of the margins (Harvey, 2005, 55). This has involved integrating 'lagging regions' into national political structures and national and regional 
economies through the expansion of state and market institutions. This approach - infused with a powerful "civilising frontier rhetoric" (Cramer \& Richards, 2011, 289) - presents states and markets as pacifying and stabilizing forces that can transform unruly borderlands into areas of licit and productive activities.

However, this narrative masks the complexity, tensions, and systems of public authority and service provision, which precede and shape interventions in these spaces. As Nancy Lee Peluso and Christian Lund $(2011,668)$ argue, the margins "are not sites where 'development' and 'progress' meet 'wilderness' or traditional lands and peoples. They are sites where authorities, sovereignties and hegemonies of the recent past have been or are currently being challenged by new enclosures, territorializations, and property regimes." Furthermore, diffusionist narratives ignore the dynamism and agency within borderland regions. These are not passive spaces awaiting integration. They are places of innovation and experimentation in their own right, the impacts of which can radiate outwards to impact on systems of power and development processes within countries and wider regions. For example, in Myanmar, the country's borderlands became key testing grounds for government efforts to liberalise the economy in the late 1980 s and 1990 s as the central government sought to capitalise on longstanding illicit cross-border economies. Furthermore, at the same time as the government launched a sustained crackdown on pro-democracy protests throughout the country, it explored new approaches for dealing with opposition in the margins through reaching ceasefire agreement with various borderland-based armed groups. Growing stability, expanding borderland resource extraction and cross-border trade (including illicit trade) generated new revenue flows that underpinned the national economy and the country's emerging private sector (including banks, airlines and private construction companies), infrastructure development and the real estate market (Meehan, 2011). 
These insights reveal a number of important challenges to the integrationist agenda. They show the need to address the 'borderland blindness' and state-centric biases inherent to policymaking. They also show the need for policymakers to engage more deeply with the causes of those borderland 'pathologies' - violence, illegality and underdevelopment - that they purportedly seek to address. In many contexts, these pathologies are less a consequence of the lack of political and economic integration in borderland regions, than a function of the way these integrative processes are imposed, resisted, subverted and brokered by multiple sets of actors, interests and relations operating across local, national, cross-border and global scales. Longstanding illegal drug economies are rarely simply the product of anarchic or ungoverned spaces. Instead, they commonly become embedded in the conflicts, negotiations and compromises surrounding how authority and markets are constituted in contested spaces.

Thinking spatially also provides an entry-point for analysing how policies 'travel', and moving beyond simplistic notions of policy diffusion from 'centres' to 'peripheries'. It draws attention to the dynamics of policy fluidity, circulation, transfer and diffusion. It shows how policy is malleable as it travels through networks and intersects with multiple, and often competing, sets of interests and how it encounters 'friction' as it moves (Tsing, 2004). By "following the policy" (Peck \& Theodore, 2012) - or the ontological journeys of policy (Ghiabi, this volume) - it becomes possible to explore how policies are negotiated and re-worked. Policymaking chains tie together diverse actors, with different or competing interests. Within the global context of the war on drugs, states may demonstrate public commitment to prohibition and eradication, while on the ground in borderlands counter-insurgency, state consolidation and revenue generation may be more pressing priorities that result in a more pragmatic engagement with drugs (McCoy, 2017) . 
Furthermore, thinking spatially reveals internal tensions and contradictions that often exist within policy fields and interventions. Intervening actors are not monolithic and tensions often manifest themselves at different scales. For example the interests and priorities of 'China's' interventions in Myanmar's borderlands look very different when viewed at different scales. At a national-level, concerns about the influx of drugs and the spread of HIV/AIDS as a result of injecting drug use resulted in the Chinese State Council establishing an Opium Replacement Special Fund, designed to support business-led poppy substitution programmes in northern Myanmar. At a provincial level, Yunnan political and business elites have viewed expanding cross-border trade and revenue flows - including those linked to illicit goods - as a key engine for economic development. Yunnan companies have primarily viewed state-level opium substitution initiatives as a way to fuel cross-border investment regardless of its impact on reducing opium production (Meehan, this volume).

Keane's (2016) research on US counter-narcotics policies in Afghanistan also reveal the ways in which policies are re-worked as they travel and become embedded in drug-affected borderlands. Aside from the disconnect between Washington and the field - 'the 10,000 mile screw driver' - within Afghanistan, agency cultures and predispositions led to turf battles and disconnects between various arms of the US intervention. The Bureau of International Narcotics and Law Enforcement Affairs (eradication), the Drug Enforcement Administration (interdiction), USAID (alternative development), and Department of Defence (counterinsurgency) all understood and framed the drugs issue in different and frequently contradictory ways, even though there was rhetorical agreement that "it was no longer just a drug problem it was an economic problem, a political problem, a security problem" (Thomas Schweich, cited in Keane, 2016, 301). 


\subsection{Time (history)}

The final pillar of our analytical framework emphasizes the importance of an historical and temporal sensibility. History is often treated merely as context or backdrop. The orientation of interventions is always forward-looking and "future positive" (Edwards, 1999). Such historical amnesia may be partly functional. There are strong incentives to put the mistakes of the past behind, and to constantly be starting with a blank slate. But an historical lens reveals how drugs and armed conflict are deeply embedded in the social relations and power structures of many borderland regions. As Martin Smith writes, in Myanmar (1999), insurgency became a "way of life"; not in the narrow sense of vested material interests perpetuating armed conflict, but rather, how longstanding armed conflict has generated its own sets of networks, loyalties and coping mechanisms, of which drugs are a key part. This points to the complex and historically accumulated entanglements between drugs and all aspects of social and economic life in the borderlands - and warns against assumptions that better integrated policies surrounding drugs, development and peacebuilding will provide a policy fix to drug issues.

History also challenges policymaking hubris and an exaggerated belief in the transformative potential of external policies (Hirschman, 1967). An historical sensibility encourages a sense of realism and perspective about the broader structural factors that shape and constrain policy and how costs and benefits of interventions are distributed unevenly across generations. Our historical political economy framework focuses less on interventions in vacuo - their professed aims and implementation - but instead concentrates on how policies interact with the preexisting terrain of social structures, material interests, power relations and belief systems. This approach reveals that interventions in contested borderland spaces are often defined by 
processes of 'bricolage' and 'sedimentation' in which interventions 'pile up' alongside preexisting structures of authority and response mechanisms (Bierschenk et al. 2002, 6; Rasmussen \& Lund, 2018, 395; Douglas, 1986; Ghiabi, 2019 and this volume). An historical lens also offers a starting point for exploring why social groups may react to policy interventions in different ways (see Sadan, Dan \& Maran, this volume).

Historical analysis also provides a lens to better understand the foundations, worldviews and genealogies of policymaking discourses, processes and regimes (Bacchi, 2009; Seddon, 2016). It can illuminate where ideas come from, how they are recycled, reinvented and repackaged, and the sets of interests that underpin policy fields and regimes. For example, the notion that development interventions can provide an antidote to the "disordered faults of progress" (Cowen \& Shenton, 1996) - a way to provide order and stability during processes of rapid and disruptive political and economic change - is an old idea whose roots can be traced back to early industrialization, but which finds itself reinvented in contemporary World Bank thinking about civil wars as development in reverse and development as an investment in security (Cramer, 2016; Duffield, 2007). A more granular historical analysis of policy regimes and institutions also provides an entry-point to understand the vested interests that drive continuities and changes within policy. Deep-seated and slow to change power structures often play a much more influential role in shaping policy decisions than evidence of policy success or failure. For example, Martin Jelsma (2015) argues that the reinvigoration of the war on drugs in the 1990s was motivated by broader historical shifts surrounding the end of the Cold War, which meant that counter-narcotics policies became an important means through which to legitimise and protect military budgets. The Pentagon became the lead agency for drug interdiction, the 1990s were declared the "Decade Against Drug Abuse", and US funding 
underpinned the creation in 1991 of the UN International Drug Control Programme (Jelsma, 2003; Jelsma, 2015).

\section{The drugs-development-peacebuilding policy trilemma}

As explored above, the integrationist position tends to skirt over the difficult tensions and tradeoffs that ensue in drugs-affected borderlands where the policy fields of drugs, development and peacebuilding converge. Dani Rodrik's (2011) notion of a policy trilemma provides a heuristic device for further exploring these tensions and trade-offs. Rodrik, in the context of international development, has challenged the liberal assumption that "all good things come together" (Hirschman, 1967) by arguing that it is not possible for countries to simultaneously pursue economic integration, national sovereignty and democratisation. Instead, he contends that countries can work towards two of these conditions, but not three at any one time. At least one of these three conditions has to be sacrificed. National policymakers, public opinion and social actors will ignore the trilemma at their own peril. This would necessarily involve downgrading or compromising on goals and understanding and making explicit - possibly at critical points - the trade-offs involved in pursuing some goals and not others.

The trilemma does not imply that the three conditions are totally incommensurate with one another, but they cannot all be pursued at the same time without some compromises. For example, pulling back on economic integration, or relaxing criteria for national sovereignty can give countries greater room for manoeuvre, with the potential to move into a constructive policy path. The trilemma has a temporal dimension in the sense that it may be possible to pursue all three goals if they are not done simultaneously but in a sequenced and gradual fashion over a long time period. 
We argue here that there is a similar kind of policy trilemma - and thus analytical framework - in relation to drugs, development and peacebuilding. It may be very difficult, if not impossible to pursue all three goals at the same time i.e. (1) A drug free world (2) Inclusive economic growth (3) Sustainable peace. For example, the assumption that the reduction of drug production is always compatible with peace, because it undercuts the access to rents by non-state armed actors can be fatally flawed in both directions: peace can come with increased drug production, and war dynamics can be tamed by pacts that allow different parties to receive its cut from relevant rents (Meehan, 2011; Snyder, 2006). Pursued simultaneously in their 'hardest' and most dogmatic forms, the trilemma becomes much sharper. Relaxing or changing the criteria of 'success' and changing the timeframes and sequencing are likely to make the trilemma easier to handle.

It is important to note that there is an asymmetry in the drugs-development-peace trilemma, firstly in the sense that whilst inclusive development and sustainable peace are widely supported as positive aspirational goals, the idea of a 'drug free world' does not command universal support. Secondly, the 'disruptive potential' of coercive drugs policies is proportionately greater, and can undermine achievement of the other two goals of development and peace.

It is also recognised that within - as well as between - each of these policy fields there are divisions, tensions and trade-offs; for example between 'harder' and 'softer' approaches to drugs; between rapid growth and broad based development; between the return of order and more inclusive forms of 'positive peace'. At the same time the trilemma is experienced unevenly by different sets of actors, within and across countries - international policymakers, 
national government officials and local civil society actors will all have different sets of assumptions about the priorities and trade-offs in relation to each of these fields.

If the policy goals, and what is regarded as 'best practice' in each of these policy fields are relaxed, then the trilemma becomes more manageable. But this involves explicit recognition of the need to sacrifice or relax certain criteria. Also if the short-term, long-term trade-off is acknowledged then perhaps the trilemma is less acute - the problem is compounded when policymakers pretend that all good things - in their 'ideal' form - can all come at once. This picture of positive convergence is very hard to sustain in borderland regions because of the particular features of these zones, as outlined above - including the centrality of illicit drug economies to local livelihoods and power structures, and the limited authority and presence of the state to provide public goods services or to enforce drug policies and peace agreements.

If the policy goal is a sustainable war to peace transition, in drug-affected borderlands, as well as at the national level, then a more explicit and deliberative weighing up of the trade- offs and distributive impacts of policies related to drugs, development and peacebuilding, is required. The key dimensions of the trilemma can be set out in the following diagram.

\section{Figure 1: The Policy Trilemma [see separate attachment]}

The trilemma is less about making mutually exclusive choices, than calibrating different sets of policies so that they are more attuned to local contexts, needs and priorities. The trade-offs between and within these policy fields are explored in turn below:

\section{Drugs}


The deleterious impacts of the war on drugs, both in terms of its stated goals and its humanitarian and development consequences have been extensively documented and are not rehearsed here in any detail.

Firstly, there is a sharp trade-off between coercive counter-narcotics (CN) policies and development processes and outcomes. The eradication of illicit crops can undermine peasant livelihoods and social safety nets without offering any other alternative, frequently undermining as well legal economies (Drugs and (dis)order, 2020). Alternative development (AD), which in many countries goes hand in hand with counter-narcotics and counterinsurgency, has failed to produce tangible developmental effects, even in its own terms. This calls into question the idea that $\mathrm{AD}$ is somehow a sub-field, like harm reduction, which is closely aligned to development goals and approaches and can thus be a vehicle for integrating drugs and development - and as such might help 'soften' or dissolve the trade-off.

Secondly, militarized and/or otherwise coercive $\mathrm{CN}$ has been shown to have a range of negative impacts on political order and sustainable peace. Paramilitarized approaches may pluralise or fragment the means of coercion, undermine or disrupt national or local political settlements, decrease incentives for armed groups to engage in peace talks, inadvertently boost recruitment into rebel groups and so forth. Therefore the trade-offs between harder $\mathrm{CN}$ policies and development and peacebuilding goals, have been widely recognized and documented.

\section{Development}

Within the policy mantra that 'all good things come together' there is the assumption that tackling drugs and promoting development are mutually reinforcing. Although the SDGs make only minor reference to illicit drugs issues, it is assumed that development will generate viable 
alternative livelihood options for those engaged in drug economies. However, our research indicates a more complex relationship between drugs and development, which implies that efforts to integrate development and drug policy agendas face difficult trade-offs.

Development may generate new forms of dispossession, exclusion and livelihood insecurity that push people into engaging with illicit drug economies. In Myanmar, the better-off are more able to profit from economic liberalisation and agricultural commercialisation than poorer households, who face worsening debt and dispossession and for whom opium cultivation becomes a means to stave off destitution (Meehan, this volume). In Colombia, coca cultivation is the alternative livelihood for rural populations who have been marginalised as a result of a development pathway defined by high levels of land concentration, worsening feasibility of family farming, and increasing inequality between the rural and urban worlds (Gutiérrez Sanín, this volume). In both cases, the involvement of rural populations in illicit economies is not simply a function of longstanding marginality and a lack of development, but is a result of new forms of impoverishment and precarity created by development processes (see also Gootenberg \& Davalos, 2018; Le Cour Grandmaison et al., 2019; Morris, 2020). Even where the aggregate impact of development has been broadly positive - economic growth, greater agricultural productivity, and so forth - the benefits and costs of development are distributed highly unevenly, and often in ways that can expose certain populations - particularly those in borderland regions - to social dislocation and trauma that manifest in forms of widespread alcohol and drug abuse (Sadan, Dan \& Maran, this volume; Alexander, 2008).

Further complicating the assumed synergy between tackling drugs and promoting development, drug economies can also have positive development effects, especially on the poorest and most marginalised. At the household level, illicit drug cultivation across 
Afghanistan, Colombia and Myanmar has provided a key 'safety net' for some of the poorest populations, and has also offered a means of social advancement. As Gutiérrez Sanín argues (this volume), the coca economy offers five key characteristics that have enabled coca to have a more positive impact on the development of rural populations than licit agriculture: coca is relatively egalitarian in terms of land tenure; it is relatively profitable even for very small landholders; it is labour intensive; it is resilient in that it can support livelihoods without state provision of public good or subsidies; and it is not conducive to monoculture, thus enabling households to cultivate coca alongside maintaining food security. Across all three countries, farmers report that illicit drug cultivation enables them to access credit and pay for basic services such as healthcare. In Afghanistan, opium cultivation has also stimulated agricultural expansion, making previously uncultivated desert land commercially viable by generating the income to invest in irrigation (Mansfield, 2016). In some cases, drug cultivation has even enabled social advancement by enabling households to invest in their children's education and to invest in new income-generating opportunities. Illicit drug economies also have wider developmental effects. They generate capital that is invested in local, national and regional economies, and they animate the expansion of trading networks into marginalised areas, thus contributing to greater regional licit and illicit commerce. Indeed, in borderland areas long neglected by central governments, revenue from illicit drug economies has also enabled communities to invest in public goods - including basic infrastructures and services - that the state has failed to provide, demonstrating how illicit economies can at times generate 'state effects'.

These tensions and trade-offs vary across different drug-affected regions. In Colombia, the opportunities that coca cultivation creates for social advancement are offset against the risks posed by eradication and by the violence that surrounds the drug economy (Drugs and 
(dis)order, 2020). In Myanmar, the benefits to local livelihoods generated by illicit opium cultivation have been increasingly offset by worsening levels of harmful drug use amongst local populations (see, Dan, Maran \& Sadan, this volume; Drugs and (dis)order, 2020).

\section{Peacebuilding}

Efforts to reduce large-scale armed violence also involve difficult trade-offs with both drugs and development policy. Negotiations surrounding the allocation of rents linked to the drug economy may be integral to stabilising political settlements that manage armed conflict in drugaffected borderlands (Goodhand, 2008; Meehan, 2011). Illicit drug economies may be an essential foundation of local power structures. These are also regions of highly fragmented sovereignty where it extremely difficult for any actor (state or non-state) to monopolise or prohibit drug production (Snyder, 2006). Informal agreements between warring parties are thus often rooted in re-working relationships surrounding illicit drug flows, rather than seeking to dismantle them (Meehan, 2015). Subsequent efforts to tackle drugs may destabilise political settlements that have coalesced around the drug economy. For example in Afghanistan, US pressure on the Karzai administration to implement opium bans destabilised local power structures, antagonised rural elites who were forced to implement bans. This delegitimized government authority in the eyes of rural populations, and opened a space for the Taliban to pose as the protectors of the peasantry from destructive and externally driven drug bans (Goodhand, 2008; Mansfield, 2016). In northern Myanmar, social movements that have mobilised in an attempt to address worsening drug harms (Dan, Maran \& Sadan; Sadan, Dan \& Maran; Maran \& Sadan, all this volume), have challenged the tacit agreements between the Myanmar army and local militias, and relationships between local authorities and rural populations involved in drug cultivation. 
Efforts to stabilise armed conflict can also result in forms of "elite capture", where elites monopolise the benefits of peace and leave little scope for sustained progressive change (Cheng, Goodhand \& Meehan, 2018, 3). Such outcomes are not simply a consequence of flawed peace negotiations that may be improved through better design and implementation in the future (Bhatia, this volume). Rather, the potential to monopolise the benefits of peace may be what enables transitions out of large-scale armed violence in the first place, and that allows these transitions to endure (Cheng, Goodhand \& Meehan, 2018). The tensions surrounding these trade-offs can shift over time. In some cases, efforts by elites to broaden their constituencies or pressures to strengthen their legitimacy may facilitate more inclusive outcomes. In other cases, elite capture has exposed populations to ongoing forms of violence, eroded public support for peace deals, and generated new conflict dynamics, as has been the case in parts of Myanmar since 2010.

Therefore, the above discussion of trade-offs shows both that 'all good thing do not come together', but also that all 'evil' does not necessarily lead to harm, in the sense that drug economies may have productive and positive effects on processes of development and peacebuilding. Whilst counter-narcotics policies have clearly undermined the achievement of SDG goals, drug economies in certain contexts may play a role in advancing them. This raises difficult challenges for policymakers that cannot be skirted over by integrationist talk.

\section{Conclusion: Managing Trade-offs and the implications of the drugs-development-peace trilemma}

Rodrik's trilemma was developed as a critique of a development policy paradigm, which assumed that the 'right' policies could be implemented irrespective of context and pursued 
simultaneously. Instead he argued that trade-offs cannot be avoided and that the choices made by national policymakers need to be informed by, and tailored to, the different histories, development paths, and constraints faced by individual countries.

We have argued above that there is a similar, though asymmetrical, policy trilemma in relation to drugs, development and peace. This leads to a conclusion, like Rodrik's, that there is a need to rethink the current integrationist agenda surrounding drugs, which does not sufficiently take into account local contexts, fundamental trade-offs and the deleterious effects of pursuing incommensurate goals simultaneously. This integrationist agenda represents primarily a policy trilemma involving three relatively discrete policy fields, focusing on choices and trade-offs between them. But our subsequent analysis of trade-offs, has revealed a more complex picture than this initial framework implies. Both the idea of a smooth integration of drugs, development and peacebuilding interventions, or alternatively the notion of sharply defined and distinct policy fields are inaccurate and unhelpful -- conceptually and empirically. In borderland sites, these fields converge, 'pile up' and become entangled with one another. Interventions are absorbed and reshaped in the borderlands, mutating as they travel, and sharp trade-offs become fuzzier as they encounter the hybrid institutions and diffuse power structures characteristic of these marginal zones. Therefore it is important to both acknowledge the complexity of these policy fields as they enter 'living' borderlands, whilst not losing sight of the value of the policy trilemma as a heuristic device to study the tensions, trade-offs, distributive effects and choices involved.

Firstly, within each of these policy fields there are significant tensions and trade-offs - for example between eradication and harm reduction, between growth and equity, between stability and inclusive peace. In each policy field there are numerous sub-fields and areas of 
contestation, so that that the meanings and goals associated with drugs, development and peace are always fluid and unstable, and shift as they travel and 'hit the ground'.

Secondly, it is unhelpful to detach ideal-type policy fields, from the phenomena themselves drug economies, processes of development and conflict and peacebuilding dynamics are key structural features and determinates of borderland contexts. And the shifting balance between these three sets of forces shape trajectories into and out of armed conflict and the sustainability of post-war transitions. The salience of each of these three phenomena in any one context, changes over time, and these shifts may only be tenuously related to policies in these three areas. For example increased investments in counter-narcotics efforts may occur alongside significant increases in drug production, as has been the case in Afghanistan. Major investments in peacemaking may take place in parallel with escalations in armed conflict. Our political economy framework shows that there is a need to keep the role of policy in perspective, without denying its importance at certain times in particular contexts. Therefore the trilemma framework needs to incorporate a 'double vision' - maintaining an awareness of both the policy field and the empirical phenomenon - and their relationship to one another. In this sense it should encourage a focus on both trade-offs and connections - but our understanding of these connections is more complex, contextualised and multi-dimensional than that of the integrationist position.

Thirdly, the policy trilemma is not about the technical issues related to 'best practice', sequencing and efficiency. We have emphasized in this paper the need to 'turn the mirror inwards' so as to engage with the political economy of policymaking. The tensions and tradeoffs surrounding the policy trilemma generates political choices. Understanding the policymaking processes and outcomes requires being conscious of who makes these choices, 
why, with what effects, and who bears the costs of these decisions. Who decides on the tradeoffs and who benefits and loses out as a result of these decisions? Rodrik (2011) argues that successful development paths have occurred when national actors have the policy space to take control and responsibility in making policies that are more attuned with local realities. The war on drugs tends to reduce the room for manoeuvre of national policymakers, leading to policies that are responsive to external rather than internal constituencies. This doesn't mean that national elites always make the right decisions, though generally they have to bear the costs of their decisions, more so than is the case with external actors. This approach also generates greater scope to engage in more meaningful ways with how borderland communities themselves confront - and seek to respond to - the tensions and trade-offs outlined in the policy trilemma. Of course, localised responses should not be seen as a panacea and can generate their own problematic outcomes. Yet, interventions are likely to fail or generate further adverse impacts where there is significant misalignment between externally-driven responses (whether by international or national actors) and local responses and priorities (Dan, Maran \& Sadan, this volume).

Fourthly, the trilemma has a strong spatial dimension - the trade-offs have ramifications beyond the national frame of reference. For instance pressures by international actors to reduce drug supply can be destabilizing and create immediate costs for domestic actors, whilst having less direct costs for international actors, at least in the short term. Policies that appear to generate aggregate benefits at the national level may produce 'negative externalities' for borderland populations. Ostensibly successful efforts at drug reduction may simply push the problem over borders - so the policy trilemma may become more manageable on one side of the border and more acute and stark on the other side. As Keen and Andersson (2018) note, the war on drugs involves a process of risk transfer onto groups and regions with the least voice, 
so again the response to the trilemma may involve displacing the problem rather than resolving it.

We have sought to emphasize the importance of a borderland lens for better understanding the spatial dimensions of policy processes and for strengthening engagement with those participating in illicit drug economies (producers, transporters or consumers) across the Global South. The perspective of those living in drugs-affected environments are poorly represented - or not represented at all - in global and national policy debates on drugs, development and peacebuilding. This approach does not automatically mean deprioritising drugs. As the Myanmar case shows, there may be domestic constituencies for counter-narcotics. Whilst in Colombia coca farmers may not see their futures as being tied up with illicit drugs, which they would happily trade for more predictable and less violent ways of making a living, so long as security and development were on offer. Instead, it reveals that borderland regions are not passive receptors of policies that diffuse outwards from the centre, but are also often sites of innovation and experimentation in addressing the tensions surrounding drugs, development and peace that borderland populations experience in their daily lives.

Fifth, the trilemma has a strong temporal dimension. As the case of the Cocaleros movement in Colombia suggests, if coca farmers had access to licit markets, and public goods including services and security, they would no longer cultivate coca, but the key point is that their version of 'development' and 'peace' would need to precede drug eradication. The trilemma is perhaps starkest and least manageable during moments of change, when pushing hard on drug issues may push countries into new rounds of conflict and undermine fragile safety nets. This does not necessarily mean 'forgetting about drugs' but the trilemma can be softened by focusing on 
harm reduction and violence reduction, rather than forced eradication during these periods of transition.

This paper has set out an analytical framework founded upon questions of power, space and time as a way to address the policy trilemma created by efforts to integrate drugs, development and peacebuilding. In doing so, this article aims to advance discussion and debate on how to engage with the tensions and trade-offs that this integrationist agenda reveals, but which have to date been largely ignored.

\section{References}

Alexander, B.K. (2008). The globalisation of addiction: a study in poverty of the spirit. Oxford: Oxford University Press.

Asad, T. (2004). Where are the Margins of the State? Anthropology in the Margins of the State. In PoLAR: Political and Legal Anthropology Review, 30(1), 279-288.

Autesserre, S. (2014). Peaceland: Conflict Resolution and the Everyday Politics of International Intervention. Cambridge: Cambridge University Press.

Bacchi, C. (2009). Analyzing policy: What is the policy represented to be. Australia: Pearson.

Bacchi, C. (2012). Introducing the 'What's the problem represented to be?' approach. In Bletsas, A. \& Beasley, C. (Eds). Engaging with Carol Bacchi: Strategic interventions and exchanges. Adelaide: University of Adelaide Press, 21-24.

Bacchi, C. (2016). Problematizations in Health Policy: Questioning How "Problems" Are Constituted in Policies. SAGE Open, April-June 2016, 1-16. 
Bell, C. (2015). What we talk about when we talk about political settlements: Towards Inclusive and Open Political Settlements in an Era of Disillusionment. Political Settlements Research Programme Working Paper 1.

Bewley-Taylor, D. R. (2014). Legitimacy and modernity via policy transfer: The utility of the 2003 Afghan National Drug Control Strategy. International Journal of Drug Control Policy, $25,1009-1018$.

Bhatia, J. (2020). Unsettling the Peace? The Role of Illicit Economies in Peace Processes. International Journal of Drug Policy (this special issue).

Bierschenk, T., Chaveau, J. \&De Sardan, J. (2002). Local development brokers in Africa: The rise of a new social category, Working Paper No. 13 Department of Anthropology and African Studies. Mainz, Germany: Johannes Gutenberg University.

Bourdieu, P. (1993). Some properties of fields. Sociology in question, 72-77.

Brombacher, D. \& Westerbarkei, J. (2019). From Alternative Development to Sustainable Development: The Role of Development Within the Global Drug Control Regime. Journal of Illicit Economies and Development, 1(1), 89-98.

Buxton, J. (2015). Drugs and development: the great disconnect. Policy Report, 2, 12.

Campbell, N., \& Campbell, N. D. (2000). Using women: Gender, drug policy, and social justice. Psychology Press.

Carothers, T., \& De Gramont, D. (2013). Development aid confronts politics: The almost revolution. Brookings Institution Press. 
Cheng, C., Goodhand, J. \& Meehan, P. (2018). Elite Bargains and Political Deals Project Synthesis Paper: Securing and Sustaining Elite Bargains that Reduce Violent Conflict. London: Stabilisation Unit.

Cons, J. (2016). Sensitive Space: Fragmented Territory at the India-Bangladesh Border. Seattle and London: University of Washington Press.

Cornell, S. (2005). The Interaction of Narcotics and Conflict, Journal of Peace Research 42(6), 751-60.

Cowen, M. \& Shenton, R. (1996). Doctrines of Development. London: Routledge.

Cramer, C. \& Richards, P. (2011). Violence and War in Agrarian Perspective. Journal of Agrarian Change, 11(3), 277-297.

Cramer, C. (2006). Civil War Is Not a Stupid Thing: Accounting for Violence in Developing Countries. London: Hurst \& Company.

Dan, S. Maran, J. \& Sadan, M. (2020). The Pat Jasan Drug Eradication Social Movement in Northern Myanmar: Origins \& Reactions. International Journal of Drug Policy (this special issue).

Das, V., Poole, D.(2004). Anthropology in the Margins of the State. PoLAR: Political and Legal Anthropology Review, 30(1), 140-144.

De Waal, A. (1997). Famine Crimes: Politics and the Disaster Relief Industry in Africa. Bloomington: Indiana University Press.

De Waal, A. (2009), Mission without end? Peacekeeping in the African political marketplace'. International Affairs, 85(1), 99-113. 
DFID. (2010). Building Peaceful States and Societies. London: DFID.

Douglas, M. (1986). How institutions think. New York: Syracuse University Press.

Drugs and (dis)order. (2020). Voices from the borderlands 2020: Illicit drugs, development and peacebuilding. SOAS University of London. GCRF Drugs and (Dis)Order: Building sustainable peacetime economies in the aftermath of war.

Duclos, J. Y. (2011). UNDP's Multidimensional poverty index. Development, 11.

Duffield, M. (2007). Conflict, Security and Unending War: Governing the World of Peoples. Cambridge: Polity Press.

Easterly, W. (2014). The Tyranny of Experts. Economists, Dictators and the Forgotten Rights of the Poor. Basic Civitas Books.

Edwards, M. (1999). Future Positive: International Co-operation in the 21st Century. Routledge.

Felbab-Brown, V. (2020). Detoxifying Colombia's drug policy: Colombia's counternarcotics options and their impact on peace and statebuilding. Brookings Institution Press.

Ferguson, J. (1990). The Anti-politics Machine: Development, Depoliticization and Bureaucratic Power in Lesotho. Cambridge: Cambridge University Press.

Fraser, S. (2016). Articulating addiction in alcohol and other drug policy: A multiverse of habits. International Journal of Drug Policy, 31, 6-14.

Fraser, S. (2020). Doing ontopolitically-oriented research: Synthesising concepts from the ontological turn for alcohol and other drug research and other social sciences. International Journal of Drug Policy, 82, 102610. 
Fukuyama, F. (2014). Political Order and Political Decay: From the Industrial Revolution to the Globalisation of Democracy. New Delhi: Profile Books.

Ghani, A. \& Lockhart, C. (2008). Fixing Failed States. A Framework for Rebuilding a Fractured World. Oxford: Oxford University Press.

Ghiabi, M. (2019). Drugs Politics: Managing Disorder in the Islamic Republic of Iran. Cambridge: Cambridge University Press.

Ghiabi, M. (2019). Informality Incorporated. Technology and the Production of Urban Space in Tehran. U3 - UrbanisticaTre, 19, 39-50.

Ghiabi, M. (2020). Ontological journeys across the Afghan-Iranian border in/out of the opium pharmacy, 1969-1979. International Journal of Drug Policy (this special issue).

Gillies, A, et al. (2019). Addressing the Development Implications of Illicit Economies: The Rise of a Policy and Research Agenda. Journal of Illicit Economies and Development, 1(1), 18.

GIZ. (2013). Rethinking the Approach of Alternative Development Principles and Standards of Rural Development in Drug Producing Areas. GIZ.

Goodhand, J. (2020). Fragility and Resilience Analysis: The Political Economy of Development in Borderlands. In: World Bank (Ed). From Isolation to Integration: The Borderlands of the Horn of Africa. Washington, D.C.: World Bank.

Goodhand, J (2020b). Beyond the narco frontier; rethinking an imaginary of the margins. International Journal of Drug Policy (this special issue). 
Goodhand, J. (2009). Bandits, borderlands and opium wars: Afghan statebuilding viewed from the margins, DIIS Working Paper, 26.

Goodhand, J. (2008). Corrupting or Consolidating the Peace? The Drugs Economy and Post Conflict Peacebuilding in Afghanistan. International Peacekeeping 15(3), 405-423.

Goodhand, J. (2008b). War, Peace and the Places In Between: Why Borderlands are Central. In Pugh, M., Cooper, N. \& Turner, M. (Eds.). Whose Peace? Critical Perspectives on the Political Economy of Peacebuilding. London: Palgrave.

Gootenberg, P. \& Davalos, L. (2018). The Origins of Cocaine: Colonization and Failed Development in the Amazon Andes. Routledge.

Gravingholt, S. (2011). From Power Struggles to Sustainable Peace: Understanding Political Settlements. Paris: OECD.

Gutiérrez Sanín, F. (2020). Tough tradeoffs: Agrarian alternatives and coca crops in Colombia. International Journal of Drug Policy (this special issue).

Gutierrez, E. (2015). Drugs and illicit practices: Assessing their impact on development and governance. Christian Aid Occasional Paper, 2017-08.

Gutierrez, E. (2020). The paradox of illicit economies: survival, resilience, and the limits of development and drug policy orthodoxy. Globalizations, 17(6), 1008-1026.

Harvey, D. (2005). Spaces of neoliberalization: Towards a theory of uneven geographical development. Stuttgart: Franz Steiner Verlag.

Heuser, C. (2019). The effect of illicit economies in the margins of the state-The VRAEM. Journal of Illicit Economies and Development, 1(1), 23-36. 
Hirschman, A. (1967). Development Projects Observed. Washington, DC: The Brookings Institute.

Hughes, C. E., \& Stevens, A. (2010). What can we learn from the Portuguese decriminalization of illicit drugs?. The British Journal of Criminology, 50(6), 999-1022.

Hunt, N., \& Stevens, A. (2004). Whose harm? Harm reduction and the shift to coercion in UK drug policy. Social Policy and Society, 3(4), 333.

Ingram, S. (2014/15). Political Settlements: The History of an Idea in Policy and Theory. State, Society \& Governance in Melanesia (SSGM) Discussion Paper. Canberra: ANU.

Jelsma, M. (2003). The Unwritten History of the 1998 United Nations General Assembly Special Session on Drugs, International Journal of Drug Policy, 14(2), 181-195.

Jelsma, M. (2015). UNGASS 2016: Prospects for Treaty Reform and UN System-Wide Coherence on Drug Policy. Washington, DC: The Brookings Institute.

Keane, C. (2016). The Impact of Bureaucratic Conflict on US Counternarcotics Efforts in Afghanistan. Foreign Policy Analysis, 12, 295-314.

Keen, D. \& Andersson, R. (2018). Double games: success, failure and the relocation of risk in fighting terror, drugs and migration. Political Geography, 67, 100-110.

Khan, M. (2010). Political Settlements and the Governance of Growth-Enhancing Institutions. Draft Paper in Research Paper Series on 'Growth-Enhancing Governance'. (Unpublished) http://eprints.soas.ac.uk/9968/1/Political_Settlements_internet.pdf Accessed: 15/05/2020.

Koehler, J. \& Moosakhel, G. (2020). A Tale of Two Borderlands: Changing Border Regimes in Nangarhar and Nimroz. . International Journal of Drug Policy (this special issue). 
Koram, K. (2019). Introduction. In: K. Koram (Ed.). The War on Drugs and the global colour line. London: Pluto Press.

Lancaster, K. (2016). Performing the evidence-based drug policy paradigm. Contemporary Drug Problems, 43(2), 142-153.

Lancaster, K., Ritter, A., \& Diprose, R. (2018). Recasting participation in drug policy. Contemporary Drug Problems, 45(4), 351-365.

Lancaster, K., Treloar, C., \& Ritter, A. (2017). 'Naloxone works': The politics of knowledge in 'evidence-based' drug policy. Health, 21(3), 278-294.

Le Cour Grandmaison, R., Morris, N., \& Smith, B. (2019). The Last Harvest? From the US Fentanyl Boom to the Mexican Opium Crisis. Journal of Illicit Economies and Development, $1(3), 312-329$.

Li, T. (2007). The Will to Improve: Governmentality, Development, and the Practice of Politics. Duke University Press.

Lu, J. (2017). Tapping into rubber: China's opium replacement program and rubber production in Laos, Journal of Peasant Studies, 44(4), 726-747.

Mansfield, D. (2016). A State Built on Sand: How Opium Undermined Afghanistan. Oxford: Oxford University Press.

Maran, J., Sadan, M. (2020). The Pat Jasan Drug Eradication Social Movement in Northern Myanmar: Legal Pluralism \& the Challenge of Everyday Justice. International Journal of Drug Policy (this special issue). 
McCoy, A. (2017). In the shadows of the American Century: The Rise and Decline of US Global Power. London: Haymarket Books.

Meehan, P. (2011). Drugs, insurgency and state-building in Burma: Why the drugs trade is central to Burma's changing political order, Journal of Southeast Asian Studies, 42, 376-404.

Meehan, P. (2015). Fortifying or fragmenting the state? The political economy of the drug trade in Shan State, Myanmar, 1988-2012, Critical Asian Studies, 47(2), 253-282.

Meehan, P. (2020). Precarity, poverty and poppy: Encountering development in the uplands of Shan State, Myanmar. International Journal of Drug Policy (this special issue).

Melis, M. and M. Nougier (2010). Drug policy and development. How action against illicit drugs impacts on the Millennium Development Goals. IDPC Briefing Paper. London: IDPC

Moore, D., \& Fraser, S. (2006). Putting at risk what we know: Reflecting on the drug-using subject in harm reduction and its political implications. Social Science \& Medicine, 62(12), 3035-3047.

Morris, N. (2020). Serrano Communities and Subaltern Negotiation Strategies: The Local Politics of Opium Production in Mexico, 1940-2020. The Social History of Alcohol and Drugs, 34(1), 48-81.

Mosse, D. (2004). Is Good Policy Unimplementable? Reflections on the Ethnography of Aid Policy and Practice, Development and Change, 35(4), 639-671.

Mosse, D. (2010). A Relational Approach to Durable Poverty, Inequality and Power, The Journal of Development Studies, 46(7), 1156-1178. 
Mosse, D. (Ed). (2011). Adventures in Aidland: The Anthropology of Professionals in International Development. Berghahn Books.

Nutt, D. (2012). Drugs-without the hot air: Minimising the harms of legal and illegal drugs. Tijdschrift voor Psychiatrie, 54(12), 1060-1061.

Paasi, A. (2003). Territory. In: J. Agnew, K. Mitchell \& T. Gerard (Eds). A Companion to Political Geography. Oxford: Blackwell.

Peck, J., \& Theodore, N. (2012). Follow the policy: A distended case approach. Environment and Planning A, 44(1), 21-30.

Peluso, N. \& Lund, C. (2011). New frontiers of land control: Introduction. Journal of Peasant Studies, 38, 667-681.

Race, K. (2011). Drug effects, performativity and the law. The International Journal on Drug Policy, 22(6), 410-412.

Raeymaekers, T. (2013). Violence on the margins: States, conflict, and borderlands. Springer.

Rasmussen, M.B. \& Lund, C. 2018. Reconfiguring Frontier Spaces: The territorialization of resource control, World Development, 101, 388-399.

Reeves, M. (2007). Travels in the Margins of the State: Everyday Geography in the Ferghana Valley Borderlands. In: Sahadeo, J., \& Zanca, R. (Eds). Everyday life in Central Asia: Past and Present.

Rhodes, T. (2002). The 'risk environment': a framework for understanding and reducing drug-related harm. International Journal of Drug Policy, 13(2), 85-94. 
Rhodes, T. (2009). Risk environments and drug harms: a social science for harm reduction approach, International Journal of Drug Policy, 20(3), 193-201.

Rhodes, T., \& Lancaster, K. (2019). Evidence-making interventions in health: A conceptual framing. Social Science \& Medicine, 238, 112488.

Ritter, A. (2009). How do drug policy makers access research evidence?. International Journal of Drug Policy, 20(1), 70-75.

Rodrik, D. (2011). The Globalization Paradox: Democracy and the Future of the World Economy. Oxford: Oxford University Press.

Sadan, M. (2013). Being and Becoming Kachin. Histories Beyond the State in the Borderworlds of Burma. Oxford: Oxford University Press/British Academy.

Sadan, M., Dan, S. \& Maran, J. (2020). The Pat Jasan Drug Eradication Social Movement in Northern Myanmar: Deep Culture \& Cultural Psychology. International Journal of Drug Policy (this special issue).

Seddon, T (2016). Inventing Drugs: A genealogy of a regulatory concept. Journal of Law and Society, 43, 3, 393-415.

Seddon, T. (2011). Explaining drug policy: Towards an historical sociology of policy change. International Journal of Drug Policy, 22(6), 415-419.

Seddon, T., Williams, L., \& Ralphs, R. (2012). Tough choices: Risk, security and the criminalization of drug policy. Oxford: Oxford University Press.

Shore, C., \& Wright, S. (1997). Policy: A New Field of Anthropology. In C. Shore, \& S. Wright (Eds.), Anthropology of Policy: Critical Perspectives on Governance and Power. London: 
Routledge.

Singleton, N., \& Rubin, J. (2014). What is good governance in the context of drug policy?. International journal of drug policy, 25(5), 935-941.

Smith, M. (1999). Burma: Insurgency and the Politics of Ethnicity. London: Zed Books.

Snyder, R. (2006). Does Lootable Wealth Breed Disorder? A Political Economy of Extraction Framework. Comparative Political Studies, 39, 943-968.

Steinmetz, G. (Ed.). (1999). State/culture: State-formation after the cultural turn. Cornell University Press.

Stepattat, F and J Larsen (2015). Global political ethnography: a methodological approach to studying global policy regimes. DIIS Working Paper: 1.

Stevens, A. (2010). Drugs, crime and public health: The political economy of drug policy. Routledge.

Stevens, A., \& Ritter, A. (2013). How can and do empirical studies influence drug policies? Narratives and complexity in the use of evidence in policy making. Drugs: Education, Prevention, and Policy, 20(3), 169-174.

Su, X. (2015). Nontraditional security and China's transnational narcotics control in northern Laos and Myanmar. Political Geography, 48, 72-82.

Sullivan, J. (2012). Criminal insurgency: Narcocultura, social banditry, and information operations. Small Wars Journal, 3(4), 30.

Surhke, A. (2011). When more is less. The international project in Afghanistan. London: Hurst. 
Tate, W. (2015). Drugs, Thugs and Diplomats. US Policy Making in Colombia. Stanford University Press.

Tsing, A. L. (2004). Friction. An Ethnography of Global Connection. New Jersey: Princeton University Press.

United Nations Office on Drugs \& Crime (2016). Outcome document of the 2016 United Nations General Assembly Special Session on the World Drug Problem: Our joint commitment to effectively addressing and countering the World Drug Problem. United Nations Publications.

United Nations Office on Drugs \& Crime. (2015). World Drug Report 2015. United Nations Publications.

United Nations Office on Drugs, \& Crime. (2010). World drug report 2010. United Nations Publications.

van Schendel. W. (2013). Making the Most of 'Sensitive Borders'. In D.E. Gellner (Ed). Borderland Lives in Northern South Asia. Durham NC and London: Duke University Press.

Woodward, S. (2017). The Ideology of Failed States. Why Intervention Fails. Cambridge: Cambridge University Press.

World Bank. (2011). World Development Report 2011: Conflict, Security and Development. World Bank.

Zigon, J. (2018). A War on People: Drug User Politics and a New Ethics of Community. University of California Press. 